\title{
Reform-Based-Instructional Method and Learning Styles on Students' Achievement and Retention in Mathematics: Administrative Implications
}

\author{
M. N. Modebelu \\ E-mail: meloodyne@yahoo.co.uk \\ C. C. Ogbonna \\ College of Agricultural \& Science Education \\ Michael Okpara University of Agriculture, Umudike. Abia State of Nigeria
}

Received: 13-02- 2013

Accepted: 26-03-2013

Published: 30-04-2014

doi:10.7575/aiac.ijels.v.2n.2p.48

URL: http://dx.doi.org/10.7575/aiac.ijels.v.2n.2p.48

\begin{abstract}
This study aimed at determining the effect of reform-based-instructional method learning styles on students' achievement and retention in mathematics. A sample size of 119 students was randomly selected. The quasiexperimental design comprising pre-test, post-test, and randomized control group were employed. The Collin Rose learning styles identification and Mathematics instrument were used for data collection. Data collected were analyzed using mean, standard deviation and analysis of covariance. Results revealed that students taught Mathematics with reform-based instructional method performed better than students taught the same mathematics content with the traditional method. Also, students' achievement in mathematics was influenced by the students' leaning styles. For effective teaching and learning in Mathematics, there should be reforms in the instructional processes, taking into consideration the influence of the students' learning styles in particular.
\end{abstract}

Keywords: Mathematics, Reform-based instructional method, Learning styles, students' achievement, Retention and Tertiary institution

\section{Introduction}

Mathematics is the language for expressing science and technology. Harbor-Peters (2001) observed that mathematics remains the pivot on which any true science can rest and no true science can succeed without the employment of mathematics skills. According to Makafi (2009), mathematics is universal not only in the way it influences the basic sciences, the applied sciences, engineering, and technology, but also in the way it has been made relevant to the development of the social sciences and the liberal arts. Despite its importance and service role, the students' involvement and achievement in the subject is still a source of worries. Part of the problem can be traced to what goes on in the mathematics classroom especially at the primary and secondary school levels. Bono (2008) observed that the mathematics classroom has traditionally been a place where students feted quietly as the teacher lecture about the proper way to complete mathematics problem. They do this by continuous independent practice in memorizing basic facts and word problems that lend themselves to a key word approach. The pedagogical goal was that students would develop proficiency in the skills being taught.

Teachers today seem to be faced with the problem of organizing instruction in such a way as to facilitate learning for enhanced students mathematical skills. Agwagah (2010) noted a continuous search for ways and means of improving children's performance in the subject. She regretted that as the search continues children's performance in the subject get worse especially at the primary school level. She asked, why do children fail Mathematics? Varied attempts have been made in reaction to the question above. Makafi (2009) stressed that the way students respond to a teacher's structured and instructional strategies depend largely on how the teacher steers the students. Agwagah (2010) stressed that children learn not only in different ways, but different rates. This suggests that learning process is never the same for different children. Hence the teacher must make clear connections between manipulative and mathematical ideas and verbal interactions in order to promote understanding. It also observed that verbalizing often clarifies concepts; talking about mathematics is an important part of thinking about mathematics. Mathematics is therefore viewed as quality opportunity to mold children into problem-solvers who can make relationship through explorations, reasoning, and exchanging ideas through discussion with others, which are essential skills in real life. Repositioning instruction in the mathematics classroom will ensure students' acquisition of relevant mathematics skills. Children learn differently and hence there is need to diversify instructional strategies and learning tasks. Taylor (2007) observed that every individual perceives and processes information in various ways according to the individual's perceptual and sensory strengths. The combination of perceiving and processing strength forms an individual's unique learning style which to a reasonable extent influence the rate and way learning takes place for the individual. Grasha (2006) defines learning styles as personal disposition 
which influences students' ability to acquire information, to interact with peers and the teacher, and to otherwise participate in a learning experience.

Taylor (2007) observed that the ever-increasing demand that students demonstrate high level competency in mathematics skills as well as in their ability to solve problems, justifies the reform in mathematics education that calls for changes that alter dramatically the way Mathematics is being taught in schools. Akingbola (2012) argued that we need an educational reform that will provide Nigerians with the skills needed to compete internationally. Reforms are imperative to free nations from future breaks of the vicious circle of policies that have stagnated or retarded them. Nigerian reform agenda has been packaged as National Economic Empowerment and Development Strategy (NEEDs) which is a grand strategy to reposition Nigeria for stability, growth, development and prosperity for all. If instructions in the mathematics classrooms are still characterized by students' quiet listening as the teacher presents works and discusses mathematics, growth, development and prosperity through education will still be a tedious task. The reform movement in mathematics education as in Bono (2008) calls for abandoning curricula that promote thinking about mathematics as a rigid system of externally dictated rules governed by standards of accuracy, speed and memory. This implies that teaching and learning styles should promte facilitation of learning, provide enough room for learners to interact with learning resources, making inquiry and coming out with new knowledge outside the already mapped out or expected as contained in the existing curriculum. Presently, secondary school curriculum in Nigeria seems rigid, as it specifies what is expected from the teacher and the learner in a particular lesson or content.

Present situation calls for urgent need to reposition instruction so that students will be greatly encouraged in solving challenging problems that entail open ended answers or that which involves the use of different strategies and adequate skills acquisition. Akingbola (2012) observed that students must listen and explain their mathematics reasoning through conversations among their teachers and peers so as to construct personal and meaningful understanding of mathematics concepts. This involves the use of class discussions, pair workarrangement, use of manipulative and short class review exercisesHabor-Peter (2001) described this type of instruction as differentiated instruction that incorporates a variety of strategies. It takes care of students' readiness, interest and learning profile. For students to be empowered and mathematically stable in achievement and learning require adequate skill acquisition and instruction facilitation in the classrooms, and must be such that can accommodate divergent learning styles of the students.

The present study addressed three learning styles which according to Modebelu and Igwebuike (2013), require observance of the child's learning styles. These are the visual, auditory and Kinesthetic/tactile styles. Ralston (2006) described the visual learners as students who learn through seeing. This requires visual aids in order to make sense of new experiences. The visual aids can be charts, drawings, diagrams or outlines. Mental images are needed as strategy to cope with learning situation that do not meet their learning style need. He also described the auditory learners as those who learn through listening. They are capable of thinking abstractly and more conceptual by nature. They are very skillful and can memorize well. The tactile learners learn faster by doing and are actively involved in doing something in order to learn or understand the learning task completely. They are creative and innovative skills that should be properly channeled by the teacher. In the light of the above and the compelling need to wage instructional war in the classrooms against poor performance of students in mathematics, the conduct of the present study seems warranted. The study aims at determining the effects of reform-based instructional method on the mathematics achievement and retention of year one students of College of Education with different learning styles. The purpose of the study is to determine the effect of a reform-based instructional method on the Mathematics achievement of students with different learning styles in mathematics. Specifically, the study purports to determine which category of the students with different learning styles benefit maximally in mathematics in a reform-based instructional method. The study investigates if retention of mathematics knowledge varies due to differences in the students' learning styles.

\subsection{Research Questions/ Hypotheses}

1. What is the influence of reform-based instructional method on the mathematics achievement of students with different learning styles as measured by their mean achievement scores?

2. What are students' learning styles with a reform-based instructional method in mathematics?

3. Which category of students benefited maximally from the reform -based instruction method in mathematics as measured by their mean achievement scores?

4. To what extent are students' means retention scores influenced by their learning styles in a reform-based instructional method?

HO1 There is no significant difference in the mean mathematics achievement scores of students with different learning styles taught mathematics with reform-based instructional method and those taught with conventional method.

$\mathrm{HO} 2$ There is no significant difference in the mean retention score of students with different learning styles taught the same mathematics contents with a reform-based instructional method and those taught with conventional method.

\section{Methodology}

The study employed a quasi-experimental design which utilized a pre-test randomized control group method. The experimental treatment used is the reform-based instructional method which involved the use of whole class discussion method and varied instructional strategies adapted to take care of the learning styles of the students. The study was carried out in Anambra State. The two Colleges of Education in the state that admit students for National Certificate in 
Education (NCE) mathematics programmes (ie. Nwafor Orizu College of Education, Nsugbe and Federal College Education (technical), Umunze) were used.

The scope was such that reform-based-instructional method was employed as experimental treatment with the identified students' learning styles. The mathematics course contents included equation of straight lines and of circles.

The population consisted of all the 119 year one students of the two Colleges of Education that offered Coordinate Geometry Mathematics in the 2011/2012 academic session.

The sample consisted of 119 year one students of the colleges who were in year one at the time of this project. Sixty one of them belong to the experimental group while the control is 58 . These students were randomly assigned to the experimental and control treatment groups.

The experimental and control groups were trained by research assistants. The experimental group was taught with reform-based instructional method while the control group was taught with the traditional expository method.

The reform-based instructional methods have the following features:

1. Varied instructional strategies were employed so as to give the students with varying learning styles opportunity of benefiting from at least one.

2. Discussion method was employed to encourage every student to talk mathematics. Other rules of discussion were observed to ensure effective participation of all.

3. Manipulates were provided for demonstration of concepts and for students' interaction so as to ensure skills development.

4. Supervised short written class exercises that featured as review given at end of each lesson.

5. The Collin Rose learning style questionnaire was administered on the students. This enabled the research to determine the varying learning styles of the students which are the auditory, visual and tactile.

6. The research assistants were the regular mathematics classroom teachers for the two institutions used.

The traditional classroom had the following features:

1. The students were taught with lesson notes tailored along traditional expository method of instruction.

2. The talking and explanation were done by the research assistants.

3. The students were given takehome assignment at the end of the day. Feedback was not immediate.

\section{Results}

Table 1. Summary of the mean and standard deviation of scores

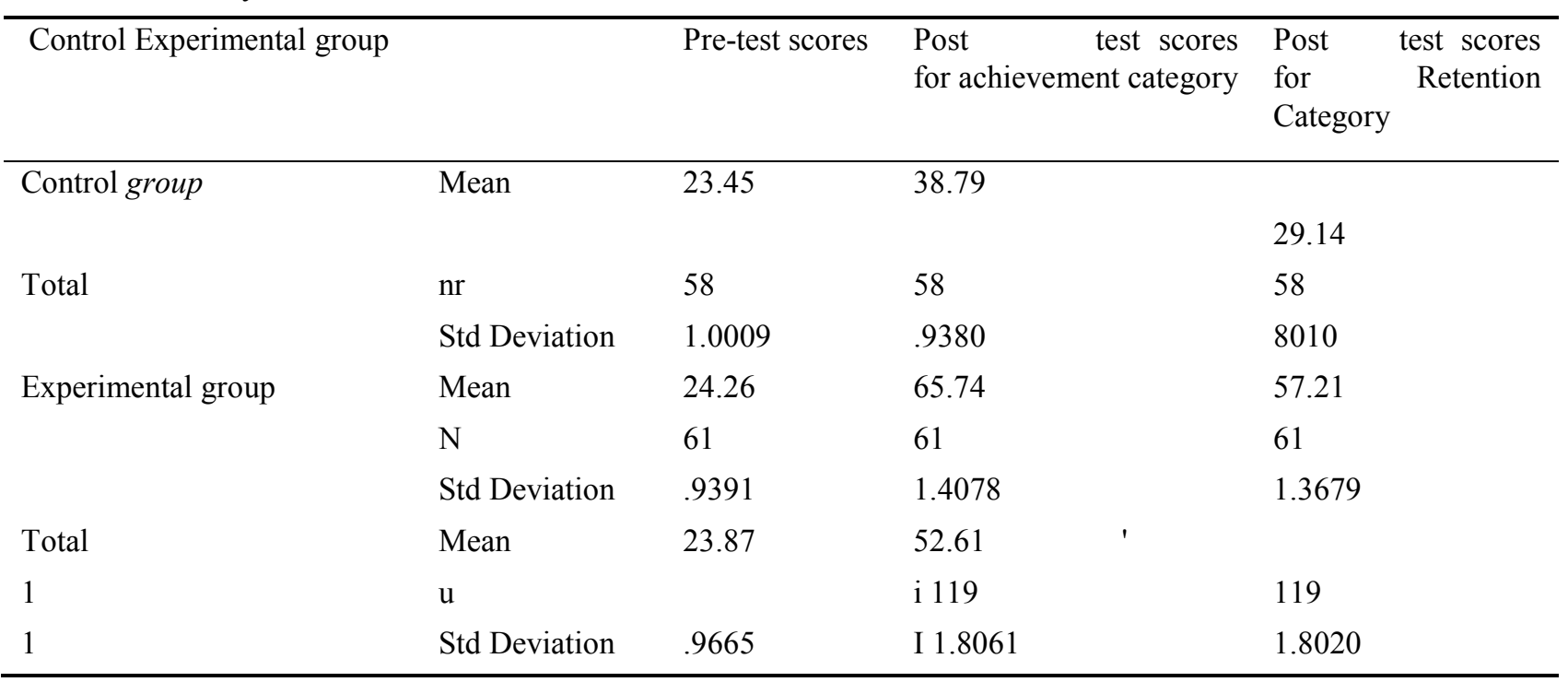

From the analysis presented in table 1 above, the experimental group had a mean achievement of 65.74 and standard deviation of 1.4078 while the control group had a mean of 38.79 and standard deviation of 0,9380 . The difference in the mean achievement suggests that experimental group who were taught with reform-based-instructional method achieved better than their counterparts of the control group.

There is no significant difference in the mean mathematics achievement scores of students with different learning styles taught mathematics with reform-based-instructional method and those taught with the traditional method. 
Table 2. Summary of the analysis of covariance of students' achievement scores

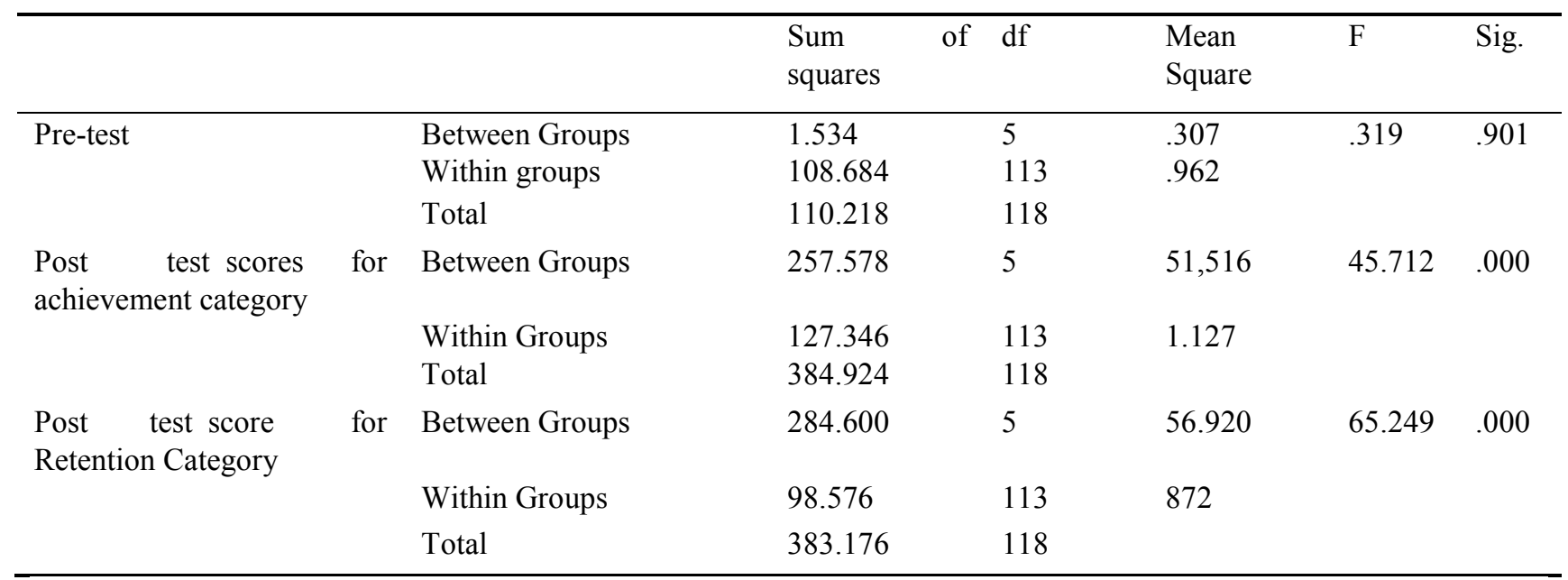

From the analysis in table two above, the f-calculated value for achievement is 45.712 with probability value of 0.000 which is less than 0.05 . The hypothesis was therefore not retained. Hence, the students' achievement in the unit of Mathematics studied was significantly influenced by the instructional method used. The students exposed to reformbased instructional method performed better than their counterparts in the control group.

Table 3. Summary of Multiple Comparison Test for Achievement Scores

Mean difference Sig.
$(10$

\begin{tabular}{|c|c|c|c|c|c|}
\hline $\begin{array}{l}\text { Dependent } \\
\text { variable }\end{array}$ & Scheffe & $\begin{array}{l}\text { Category } \\
\text { group }\end{array}$ & $\begin{array}{l}\text { Category }(\mathrm{J}) \\
\text { groups }\end{array}$ & & \\
\hline $\begin{array}{l}\text { Post test scores for } \\
\text { achievement category }\end{array}$ & & $\begin{array}{l}\text { Experimental } \\
\text { visual }\end{array}$ & $\begin{array}{l}\text { Experimental } \\
\text { tactile }\end{array}$ & 1.7538 & .000 \\
\hline & & & & & .839 \\
\hline & & & Exp. auditory & .4538 & .839 \\
\hline & & Exp. auditory & Exp. visual & -.4538 & .030 \\
\hline & & & Exp. tactile & 1.30 & .000 \\
\hline & & Exp. tactile & Exp visual & -1.7538 & .030 \\
\hline & & & Exp. auditory & -1.30 & \\
\hline
\end{tabular}

From the multiple comparisons as seen in table 3 above, the source of direction of significance in the mean achievement scores is from the visual and auditory learners' mean achievement scores which are significantly greater than the mean achievement scores for the tactile learners.

Table 4: Summary of the mean and standard deviation scores of students' achievement and retention scores by learning-styles

\begin{tabular}{llllllll}
\hline Group & \multicolumn{3}{c}{ Achievement } & & \multicolumn{3}{c}{ Retention } \\
& No & $\begin{array}{l}\text { Mean } \\
\text { Pretest }\end{array}$ & $\begin{array}{l}\text { Mean } \\
\text { Post } \\
\text { test }\end{array}$ & $\begin{array}{l}\text { Standard } \\
\text { deviation } \\
\text { Pretest }\end{array}$ & $\begin{array}{l}\text { Standard } \\
\text { Deviation } \\
\text { Post test }\end{array}$ & Mean & S.d \\
\hline Visual & 26 & 25 & 72 & .94 & 1.0 & 66.92 & 1.01 \\
Auditory & 20 & 24 & 67 & .87 & 1.1 & 52.0 & 1.11 \\
Tactile & 15 & 23 & 54 & 1.04 & 1.7 & 47.33 & 1.16 \\
\hline
\end{tabular}

From the analysis in the table above, the mean achievement scores of the visual, auditory and tactile learners of the experimental groups are 72, 67 and 54 respectively. The visual learners had the highest mean achievement score (72) while the tactile learners had the least. Achievement in Mathematics was influenced by the students' learning styles. The above also provides answer to research question four, the visual learners benefited maximally in the Mathematics unit studied in a reform-based instructional method. 
From table three presented earlier, the mean retention scores of the visual, auditory and tactile learners of the experimental group are 66.92, 52.0 and 47.33 respectively. The marked difference in the mean score suggests that students' retention of Mathematical knowledge was influenced by their learning styles in a reform-based instructional method.

There is no significant difference in the mean retention scores of students with different learning styles taught the same Mathematics contents with reform based instructional method and those taught with the traditional method.

From the analysis presented in table two, the calculated f-ratio for retention is 65,249 with probability significant value of 0.000 which is less than 0.05 . The null hypothesis of no significant mean difference in retention was therefore not retained. Hence, retention of Mathematics knowledge among students with different learning styles was influenced by the instructional method employed. The students exposed to reform-based instructional method retained more knowledge that those taught the same Mathematics units using the traditional method.

Table 5: Summary of multiple comparison tests for retention

\begin{tabular}{|c|c|c|c|c|c|}
\hline $\begin{array}{l}\text { Dependent } \\
\text { variable }\end{array}$ & Scheffe & $\begin{array}{l}\text { Category group } \\
\text { (1) }\end{array}$ & $\begin{array}{l}\text { Category } \\
\text { groups }(\mathrm{J})\end{array}$ & $\begin{array}{l}\text { Mean difference } \\
\text { UO) }\end{array}$ & Sig. \\
\hline \multirow{6}{*}{$\begin{array}{l}\text { Pest-test scores } \\
\text { for retention } \\
\text { category }\end{array}$} & Scheffe & $\begin{array}{l}\text { Experimental } \\
\text { Visual }\end{array}$ & $\begin{array}{l}\text { Experimental } \\
\text { auditory }\end{array}$ & 1.4923 & .000 \\
\hline & & & Exp. Tactile & 1.9590 & .000 \\
\hline & & $\begin{array}{l}\text { Experimental } \\
\text { Auditory }\end{array}$ & Exp. Visual & -1.4923 & .000 \\
\hline & & & Exp. Tactile & .4667 & .828 \\
\hline & & $\begin{array}{l}\text { Experimental } \\
\text { Tactile }\end{array}$ & Exp. Visual & -1.9590 & .000 \\
\hline & & $\begin{array}{l}\text { Experimental } \\
\text { Auditory }\end{array}$ & -.4667 & .828 & \\
\hline
\end{tabular}

From the analysis of the multiple regression comparison presented in table 5, the visual learners retained better the mathematics knowledge acquired more than the auditory and tactile learners. This finding is in agreement with Agwaga (2010) that stressed that children learn not only in different ways, but different rates. The implication is that teachers should recognize that children learn differently at such, there is need to diversify instructional strategies and learning tasks.

\section{Conclusion}

The students' achievement and retention of mathematics knowledge was significantly influenced by the reform-based instructional method. Achievement and retention of mathematics knowledge was also influenced by the students' learning styles.

Recommendations

Mathematics teachers should to approach the teaching and learning of mathematics with instructional methods that are learner centered, challenging and promtes skill development. Such methods should provide opportunity for continuous assessment, and immediate feedback function as well as adequate opportunity to demonstrate mathematics skills.

\section{References}

Agwaga, R.U. (2010). Differentiated instruction implications for UDL implementations. National Centre for General Curriculum. http://www.kSaclesceuter, traininresource/udl/diffinstruction.asp.

Akingbola, B. M. (2012). Occupational change and stability of industrial education graduates. Nigeria Vocational Journal, 6(3) 111-118.

Grasha, F.A. (2006). Teaching with styles. A Practical Guide for Enhancing Learning by Understanding:Teaching and Lea Styles. USA: Alliance Publishers.

Harbor-Peters, V.H.F. (2001). Mathematic language for the millennium: Implication to the society. Proceedings of September 2000 Annual Conference.

Makafi, L. (2009). Knowing and Teaching Elementary Mathematics. New Jersey: Lawrence Eribaum Association.

Modebelu, M.N. \& Igwebuike, F. K. (2013). Nigerian child learning styles: A teaching strategy for achieving effective education in Nigeria. Journal of Educational and Social Research, 3(6), 1-9.

Bono, P. O. (2008). Reform for Stability and Growth. Address presented at the retreat for Honourable Ministers and Permanent Secretaries at Nicon Hilton. Abuja July 18-20th.

Ralston, J. (2006). How own child learns? Health Library. Lasa: Mayoclinic Com.

Taylor, M. (2013). Opinion safe. Learning Style from Inquiry, 4 (1), 219-226. http://www.journals.aiac. org. au/ index.php/IJELS 